\title{
The Problems Faced by Homeless Older Adults in Nigeria: Implications for the Future Care of the Elderly
}

DOI: $10.36108 / \mathrm{NJSA} / 4102 / 12(0180)$

\author{
Joseph Hellandendu \\ Department of Sociology \\ Ahmadu Bello University \\ Zaria
}

\begin{abstract}
In the absence of a universal old age social security, the norm in Nigeria is for younger relatives to care for their aged parents and other older relatives. This was quite feasible in the agrarian economy, which is now being replaced by organized economy which is characterized by migration in search for jobs. This condition is further worsened by poverty among the youth. Some older citizens are rendered homeless in the present economic dispensation. They live on the streets and other public places and beg for sustenance. This paper brings to limelight the plights of the homeless older citizens in terms of their lives on the streets. The homeless older citizens are often grouped with able-bodied younger vagrants, arrested and confined in near total institutional settings when government wishes to rid the streets of vagrants. It is recommended that the National Population Commission, through its five yearly Demographic and Health Survey exercises should obtain reliable information on the number and locations of homeless older citizens and those who are likely to be homeless in the near future with the view to providing them with shelter and a universal welfare package.
\end{abstract}

Keywords: older adults, homelessness, begging, care, welfare

\section{Introduction}

Elderly citizens in Nigeria are expected to be supported by their younger relatives, especially their own children when they become too old to care for themselves (Okumagba, 2011; Aboderin 2004). This expectation is, however, being crippled by growing unemployment, underemployment, poverty, urbanization and modernization which interfere with younger members' ability to live in close proximity with the elderly citizens to render such assistance to the aged (Ajomale, 2007; Ottong, Bassey and Bassey, 2005; Federal Office of Statistics, 1998). As a result, among the vagrants found roaming the streets, begging for means of livelihood include older citizens aged 65years or older who should have been taken care of by their adult children, other younger relatives or by a social security system for the elderly where such exists (Heida, 2012).

According to the United Nations Centre For Human Settlements (UNCHS, 2000), homelessness is the lack of a permanent place of abode and connotes poverty and a lack of permanent employment. It can be seen as a condition of detachment from society, characterized by the lack of the affinitive bonds that place people into their social structures. A more wide-ranging interpretation of 
homelessness includes those in overcrowded, insecure or substandard accommodation and those forced into involuntary sharing of shelter.

Various measures have been put in place in the developed countries to provide welfare schemes in forms of social security, institutional care, home care, Medicare, special old peoples housing schemes, shelters for the homeless and special feeding arrangements, among others for older adults who otherwise would lack the basic necessities of life in the developed countries (Novak, 2008; Heida, 2012). On the contrary, in sub-Saharan Africa, providing support for older people is still primarily a family responsibility, supplemented by other informal mechanisms such as kinship networks and mutual aid societies, with the notable exceptions of Botswana, Mauritius, Namibia, and South Africa, where considerable welfare schemes are provided for their aged citizens (Gillian, Turner, Bailey and Latulippe, 2000). In Nigeria, states such as Ekiti, Osun, Lagos and a few others have made various provisions to cater for older adults, either financially or through the provision of vagrant/rehabilitation shelter (Aboderin, 2004: 59b; Igbinovia, 2013 ).

Homelessness is caused by a variety of factors working synergistically to precipitate the state of being unable to afford a home. Personal characteristics, family background and structural factors work in various ways against an individual to culminate in homelessness. These personal factors include drug and alcohol misuse, poor physical health, mental health breakdown and breakdown in cordial relationship among relatives which makes co-residents in a home to part ways. Homelessness could be due to having been under institutional care, such as being in the military, prison or other types of total institution, during which the person did not make arrangements for a personal place of abode and did not find one on being discharged from the institution. Structural factors which could cause homelessness include; unemployment, lack of affordable housing and housing policies that are unfavorable to some people.

In Nigeria, in addition to the personality and structural factors that render people homeless, natural disasters such as fire outbreaks, floods, violent communal conflicts and insurgency also render people homeless (NEMA, 2008). This paper examines the plight of homeless older citizens in Nigeria in terms of the hardship they face on the streets. The information presented are from secondary sources especially research reports, newspapers report and the internet. These will provide glimpses on what needs to be done to provide succour for Nigeria's homeless senior citizens

\section{Theoretical Framework}

Homelessness is a social problem. This is so in the sense that it constitutes a devastating experience for the elderly and their families. It disrupts virtually every aspect of family life, damaging the physical and emotional health of the elderly, and frequently resulting in the separation of family members. Thus, homelessness among the elderly can be 
analyzed from a sociological perspective. This paper therefore is anchored on Marxian political economy theory. Karl Marx expounded political economy theory in 1968. In the words of Marx (1968), it is not the consciousness of men that determines their being, but on the contrary, their social being determines their consciousnesses. As a framework, political economy emphasizes the crucial importance of material conditions in understanding and explaining social existence, and in finding solutions to the problems of man. It assumes that human behaviour is motivated by the survival and domineering instincts in man. Such instincts are exhibited primarily in the economic and political sphere of life, among others. Furthermore, political economy theory argues that all aspects of social life namely politics, law, social relations, housing, belief system and the economy- are all interrelated and interdependent, but that the economic sphere serves as the determinants for the politics, law, social relations, etc of any society. This is not surprising, since survival is the most basic instinct of man, after which humans attempt other things (Olatunji, 2012).

From the foregoing, this paper argues that homelessness among the elderly manifests from the fact that the Nigerian government had failed to provide basic needs (housing, health, adequate feeding, and so on) for the elderly in the country which is entrenched in section 16 (2) (d) of the Federal Republic of Nigeria (Federal Republic of Nigeria, 1999). By extension, the elderly are being excluded from having access to all that makes life meaningful, while also marginalizing them from mainstream society. This is closely allied to negative social and personal attitudes that construe ageing as a state of diminished capacities. This concern can be translated into rejection, isolation, neglect, victimization and disempowerment of older people. Thus, fellow citizens and even children who should normally defer to elders subject homeless older citizens to a high level of disdain.

The government, which should protect the elders, fails to honour the provision of shelter for the aged. In Nigeria, successive national governments have been accepted in principle as part of their National Development plans, to ensure that all citizens have access to a relatively decent and affordable housing. Along this direction, it introduced and established a National housing policy with the aim of providing an institutional framework for ensuring adequate housing both quantitatively and qualitatively (Federal Government of Nigeria, 1991). In spite of these efforts, little or no success has been made to meet the 
housing needs of the present crop Nigerian senior citizens who bear more brunt Homelessness (National Affordable Housing Association, 2006).

\section{Homeless Older Citizens in Nigeria}

The 1991 National Census figures of Nigeria stated that there were a total of 34,179 homeless people in the country as at then (National Population Commission, 1998). ${ }^{1}$ Those aged, 60 years or older constituted $41 \%$ of the homeless. State policies on the welfare of the aged in Nigeria include the Pension Act (2004) which was primarily for workers in the formal sector and the Old People's Act (2009). The care and provision of shelter for aged citizens have also been provided for in the Constitution of the Federal Republic of Nigeria, the provision has been accommodated through all the revisions that took place in section (16) sub-section (2)(d), since 1979 through 2011; "old age care and pensions are provided for all citizens". This stipulated the provision of basic welfare and protection of the rights of older people (Obasharo-John, 2011).This is far from being implemented, as it applies to only a few senior citizens who have worked in the formal sector of the economy. The 2009 Old People's Act is yet to be implemented in most states in Nigeria. The constitutional provision and welfare policies on older citizens suggest willingness by the Nigerian government to provide welfare package for older citizens, but these are yet to be well implemented in the country.

On the welfare of older adults in Nigeria, children have been taking care of their old parents. This expectation is quite difficult to maintain in the present dispensation, where more than $83 \%$ of Nigerians are poor (NBS, 2007). Unemployment is still as high as $42.4 \%$ among the working age group (1564years) who constitute about $48 \%$ of the population (NDHS, 2008). Despite this, the Nigerian government still expects the traditional arrangement of, younger relatives caring for the older citizens to continue (Aboderin, 2004). Another important avenue of assistance to the aged is begging from individual members of the public, despite the governments' displeasure against the practice of street begging (Ajomale, 2007).

However, some states have made efforts to care for their homeless senior citizens. The Ekiti State Government is noted to have taken the lead in this regard in Nigeria, it ratified and started implementing a welfare scheme which provides for the payment of $\$ 5,000$ Naira monthly to all jobless indigenes who are 60 years or older (Fayemi's Care for the Aged in Ekiti, 2014). However, the amount paid to individuals is below the minimum wage and below the $\$ 2$ dollar per day poverty level set by the United Nations. Other states have basically expressed their disapproval for living on the streets

\footnotetext{
${ }^{1}$ DHS (2008) sampled regular households, therefore did not specify homeless households for analysis.

NPC (2006) jointly analyzed homeless and regular households.
} 
through forceful removal of those living in public places, including the elderly (Uzondu, 2010; Olugbile, Coker and Zacchariah, 2014).

Nigeria's stance on homeless older citizens becomes clearer when it resorts to the removal of all homeless people living on the streets of large towns to make- shift emergency rehabilitation centres, when playing host to international events. Thus in 1977 when Nigeria hosted the Second All-Black and African Festival of Arts and Culture, the street dwellers termed "beggars" in Kaduna town, where the equestrian arts took place, irrespective of age were removed from the streets to a makeshift rehabilitation centre amidst protests which continued at the rehabilitation centre where they were kept (Anonymous 1977).

Some studies of street beggars living in homeless conditions in Nigeria have revealed that older adults in their 60 s or older, constitute a significant proportions of the samples. For example, in a study of a random sampling of 597 homeless people, in three Nigerian towns; namely, Kano, Ibadan and Enugu, Adedibu and Jelili (2011a) established that older adult 60 years or older, constituted $6.4 \%$ of the sample.

In Ola and Olalekan's (2012) study of elderly people's abuse in Ekiti, it was found that 31.8 per cent were 70 years or older. A large proportion of the respondents, 47 per cent were married and 51.4 per cent were still working. These findings suggest that a substantial proportion of the older citizens were still working during their retirement years given that 60 years is the formal age of retirement in Nigeria. In accordance with the hardship they suffer, a large proportion of the sample $(60.9 \%)$ complained that they suffered the problem of "abandonment" which connotes various forms of neglect by one's significant others especially one's own grown up children, nephews, younger siblings and other members of the corporate kin group. It also implicates institutions such as the government or private sector organizations one is or has been affiliated to. This is a kind of desperation which suggests; most complainants may not have helpers in their state of tribulation.

This feeling of despondency was also found in a study of homeless elders aged 68-82 years in Ile-Ife who were victims of an earlier violent communal conflict in Osun State by Fajemilehin, Ayaniran and Salami (2007). It was found that all the sixteen homeless older adults identified and interviewed were desolate. It was evident from the interviewees' responses to questions posed to them that they had suffered abject poverty, hunger and exposure to other health hazards. One of them is reported to have said:

When I think of those to take care of me but who have died with the conflict in the community, I would want to cry. No one is wandering about the community, it is difficult to eat, to sleep and sometimes small children see you as a mad person and want to stone you. (Fajemilehin et al., 2007: 164) 
The health implications of the situation of these internally displaced homeless older adults are quite obvious. They were poorly fed, slept on the streets and did not have relatives they could turn to for help. Besides they were still nursing the trauma of the loss of their loved ones. This set of older adults should have attracted the attention of the social welfare system, having reached the retirement age (68-82 years) that would have entitled them to welfare benefits, had a universal old age social security policy been in place. Instead of any form of help for them, they have been ignored by adults, the government and being taunted by children.

Some situations in Nigeria, however, raise doubts about who is genuinely in need of social welfare services. There are some cultural groups among whom begging are an ascribed profession for various cultural reasons (Fasasi, 2013). Begging in this case becomes a kind of socially approved source of income from which participants may amass wealth. Some "beggars" earnings may even exceed the minimum monthly wages. There is, for instance, an anecdote of beggars in Lokoja, the capital of Kogi State, who organize begging in a business fashion. The beggars have an association with which all fellow beggars must register. The group has an ethical code of conduct. Their current leader owns houses some of which he rents out, two cars and a motorcycle (Bello, 2013). Other beggars could be similarly successful (Eseme, 2013).

Begging by the older homeless citizens cannot be substituted for a national welfare programme. Its practice borders on ethical concerns about whether people should live a life of dependence on others. Moreover, the benefits of begging are selectively distributed in favor of those who are willing to beg.

\section{The Institutional Care of the Older Homeless Adults in Nigeria}

The institutional care of the homeless older adults is poorly developed in Nigeria, despite a provision for providing such aged homeless shelters for them in section(16) sub section (2d) of the country's constitution from 1979 through 2011.Contrary to this constitutional provision for older citizens, some Nigeria Government agencies tend to resort to punitive measures against vagrant older citizens they come across in performing their task of clearing the streets of street dwellers (Fasasi, 2013; Alum, 2012). It is obvious that when the homeless are generally rounded up from the streets and taken to "rehabilitation" camps, or "repatriated" to their respective places of origin, the senior citizen among them are treated the same way as the younger vagrants. The objective is to rid the street of the nuisance of all vagrants. At the rehabilitation centres, there are hardly any programmes of rehabilitation. The conditions in which they live could be similar to total institutions (Fasasi, 2013). All those identified as vagrants at public places are forcefully taken for the "rehabilitation" centre's which may pass for a concentration camp situation (Alum, 2012). The following excerpt from a report on a one time Minister of the Federal Capital Territory, Abuja, who wanted to "empower" beggars, which included homeless older adults speaks for itself on the germanises of the endeavour: 
Senator Bala Mohammed (the erstwhile Minister of FCT Abuja) in a renewed effort to take beggars off the streets has directed the FCT Social Development Secretary to empower 200 physically challenged beggars. Newsworld learnt that the vocational training aims at giving the beggars a sense of belonging and make them self-reliant. In this pursuit, the Minister has reinstated (sic) that his administration has not lowered its zero-tolerance on street begging. He revealed that his administration has started repatriating beggars found on the streets to their states of origin. Indeed, recently 59 beggars were arrested by the Task Force and sent to their respective states. Among them were women with children, physically-challenged and elderly. (Uzondu, 2010: 1)

Nigerian vagrants are often unwilling of to live in such enforced, usually poorly equipped institutional shelters due to several factors. According to Ottong, Bassey and Bassey (2007), the cultural heterogeneity of Nigeria poses problems for the inmates lumped in such enclosed spaces. They are unable to replicate the types of community lives they had lived in their places of origin in the institutions. The tones of the report on the aims and objectives of the supposed rehabilitation exercises cited above presents the beneficiaries as unwanted people. In fact force is applied to physically evacuate the homeless for rehabilitation from the streets. This could be a form of deportation (Oboh, 2011; Onoyase, 2010). However, Adedibu and Jelili (2011b), based on their own earlier study in Ibadan, Kano and Enugu have made a comprehensive set of recommendations on how the government should best intervene to assist people that are to be so (forcefully) relocated which includes the homeless aged.

It is charitable organizations and philanthropists that tend to be more concerned about the aged than the government in Nigeria. According to Ajomale (2007), NGOs and faith-based organizations such as the African Gerontological Society, AGES Nigeria, the Catholic Church, and the Sorophormist Society are examples of organizations in Nigeria that contribute effectively to the service provision to older people through day-care centres, residential homes and libraries. It seems that the underprivileged older people in Nigeria tend to be more willing to receive assistance from these charitable organizations and individuals than form the government welfare system. For instance, 71.8 per cent of beggars in Kano, Ibadan and Enugu in Adedibu and Jelili's (2011a) study received alms amounting to N500 or more daily, which amounts to about N15,000 per month. This was two times the minimum wage of N7,500 for white collar workers in Nigeria at the time of study.

Jiboye's (2001) study of a sample 200 homeless people in Itire area of Lagos, showed that no institutional care was available to them. Some of them 
lived in makeshift tents under overhead bridges, broken down vehicles, abandoned buildings, shades in motor parks or sheds in streets. They complained that they were exposed to risks of being attacked by criminals and lunatics. They also felt that they lost respect in the sight of other people. Some of them did odd jobs for which they earned as little as $\$ 2,000$ per month. The amount earned in this case is below the basic subsistence level. Under these circumstances some of their children resort to begging, prostitution and other odd jobs to supplement the parents' earnings. This again is an instance of selfdisbursement and the profanation of self as Goffman (1963) described people in similar situations.

\section{Future Care of Older Citizens in Nigeria}

The foregoing review of literature on the situation of homeless older citizens in Nigeria has shown that they are stigmatized by members of the general public and neglected by the government. In some cases, even members of the consanguine kin groups dislike their homeless kin to the extent that, both the estranged homeless person and those who have remained at home are unwilling to be reunited when opportunities arise for such reunion.

Although, most of the studies reviewed in this paper have not dwelt on the socio-demographic characteristics and causes of older citizens homelessness, Fajemilehin, Ayandiran and Salami (2011) attributed the cause of homelessness of the sample aged 68-82 years studied in Ile-Ife, to the IfeModakeke crisis in 1990s.Nigeria is still experiencing similar crisis, especially in the North-Eastern geo-political zone in Borno, Bauchi, Yobe, Gombe and Adamawa States, where hundreds of thousands of people have been rendered homeless due to the ongoing insurgency (The City Reporters, 2014). Natural disasters including (fire-outbreaks and rainstorms) also render people "Nigerians" homeless, irrespective of age (Olori, 2006; NEMA, 2008). These will add to the number of homeless elders who already constitute about $6 \%$ of homeless Nigerian's found in the streets of urban areas in the country as already cited in the study.

The homeless older adult will pose a more serious problem to rehabilitate because they are too old to work. Most of them are unable to work to earn the money to rent or build homes for themselves. Government will therefore need to implement the provision made in the constitution of the Federal Republic of Nigeria to provide shelter for all older citizens. This can be done by building shelters for homeless adults, where deserving homeless older adults can be accommodated and catered for in the form of assisted living and has hospice services at the end of their lives. It behoves Nigeria to put a social security system in place which will enable older adults pay for their own needs for survival.

\section{Discussion}

Small sample studies in some locations have shown that up to $6.4 \%$ of destitute found living and begging on Nigerian streets are older adults in their 
60s or older. These senior citizens live on the charity of fellow citizens with virtually no assistance for shelter and other welfare services. Some of the aged are in poor health exhibiting physical disability and mental health problems (Igbinovia, 2013). These suggest that the Nigerian government is yet to put in place a comprehensive package of welfare services for older citizens. The homeless older citizens have been found going hungry, sick and desolate on the streets.

There are several structural problems that may affect the zeal of the Nigerian government in coming to the aid of homeless older persons in Nigeria. One of these is that the government expects the traditional norm of children providing for their aged parents to continue, although, the ability and willingness of younger family members to cater for their helpless older relatives is dwindling, considering the high rate of unemployment among the youthful population (DHS, 2008). Another problem is the grouping of homeless older adults with younger vagrants as beggars, thereby creating a nebulous group, whose material needs are more difficult to cater for than that of the homeless older adults alone.

\section{Conclusion}

The review reveals the need for in-depth examination of the situation of the elderly in Nigeria on why some are homeless, the type of lives they live, the type of care they need and several other issues and interests of the aged. Moreover, no study was identified on the plight of older citizens in rural areas. In addition the national census of 1991 (National Population Commission, 1998) provided only the homeless status of senior citizens and not their health status or means of livelihood. It is therefore necessary to gather national data on the living conditions of the elderly 60 years or older, who constitute up to $6.8 \%$ of Nigeria's population projections (with the view) to designing strategies for providing shelter for those who are or may become homeless in the future.

\section{Recommendations}

Nigeria's National Population Commission, based on reliable national figures, should determine the number of homeless older adult citizens at various points in time in various parts of the country which should be applied in making plans for institutional care for the older homeless citizens where necessary. To achieve this, local government authorities should facilitate the enumeration of the senior citizens in their respective political wards. The variables required should include the state of the houses in which older citizens live, the adequacy of their feeding arrangements, the availability and reliability of younger relatives within the corporate consanguine group, of each older citizen, who could help provide shelter for the senior citizens when needed. This would help in ascertaining the number of senior people for whom institutional housing will 
necessarily be provided in times of crisis that may occur at various points in time.

The three tiers of government should make plans ahead of the crises point to provide Senior Housing Scheme and transit shelters. The Nigerian Government should, for all welfare purposes consider homeless older adults as a group to which special attention should be paid in providing assistance for shelter in times of crises such as violent communal crises, insurgence and natural disasters.

Adedibu and Jelili (2011a) suggested that, the government should set up adequate infrastructure to provide shelter for the homeless aged. After which the government can enact a law against Vagrancy and require the cooperation of individuals, agencies and private organizations, to prevent vagrants living in their respective premises. Thereafter, the government should institute a special police patrol team to evacuate vagrants off the streets on sight.

\section{References}

Abdulrahman, P.A. 1988. The Sociology of the Aging Process. A Paper Presented at the Conference on the Aged in Sokoto State.

Aboderin I. 2004. Decline in material family support for older people in urban Ghana, Africa: Understanding processes and causes of change. Journal of Gerontology. [PubMed]. 59B(3): S128-S137.

Adedibu, A.A. and Jelili, M.O. 2011a. Characteristics and Types of Beggars in Nigerian Cities: Implications for Public Policy." Centerpoint Journal, Humanities Edition. 14(1): 144-167.

Adedibu, A.A.; Jelili, M.O. (2011b). Packaging for Controlling Street Begging and Rehabilitating Beggars and the Physically Challenged in Nigeria: Paper for Policy Consideration. Global Journal of Human Social Science. USA: Global Journals Inc. 11(1): 16-24.

Ajomale, A. 2007. Country Report: Aging in Nigeria - Current State, Social and Economic Implications. ISA RCII, Sociology of Aging. Via www.rc11-sociology-of-aging.org/system/files/Nigeria\%202007_0.pdf Accessed 02/01/2014.

Alum, G. 2012. Evacuation of Destitute from the Federal Capital Territory. Via http:www.nigeriancommentaries.com.

Anonymous. 1977. Camped Kaduna Destitute now Protest. New Nigeria (Newspapers). 25/01/1977.

Bello, U. 2013. Life Has Been Good to Me Says Kogi King of Beggars. Weekly Trust. 29th June. Via http://www.dailytrust.com.ng/weekly/index .php/new-news/13093-life-has-been-good-to-me-says-kogi-king-ofbeggars.

Gazetted Amended Constitution of The Federal Republic of Nigeria. 2011. First and Second Amended Constitution of the Federal Republic of Nigeria. Abuja: Federal Republic of Nigeria.

Federal Republic of Nigeria. 1999. Constitution of The Federal Republic of Nigeria. Lagos: Federal Government Press. 
The Federal Republic of Nigeria. 1979. The Constitution of The Federal Republic of Nigeria. Kaduna.

Eseme, N. 2013. Roadside Begging; Lucrative Business in Abuja. Via http://www.nigerianpilot.com/roadsied-begging-lucrative-business-abuja.

Fajemilehin, B.H.; Ayandiran, E.O. and Salami, K.K. 2007. Elderly Destitution in Ile-Ife Community of Osun State, Nigeria. International Journal of Nursing Practice. 13: 161-165.

Fasasi, O.N. 2013. Menace of Professional Beggars on the Streets." Via http://nigeriancompass.com.

Fayemi's Care for The Aged in Ekiti. 2014. Via http://ekitistate.gov.ng /2012/04/fayemis-care-for-the-aged-in-ekiti-2/.

Federal Office of Statistics. 1998. Review of the Nigerian Economy 1997. Federal Office of Statistics: Nigeria.

Federal Government of Nigeria. 1991. Nigeria National Housing policy. Abuja. Federal Government of Nigeria.

Gillian, C.; Turner, J.; Bailey, C.; Latulippe, D. 2000. Social security pensions: Development and reform." Geneva, Switzerland: International Labour Office.

Goffman, E. 1963. Stigma: Notes on the Management of Spoiled Identity. Eagle Wood Cliff: Prentice-Hall Inc.

Heida, T. 2012. Political Institutions and Elderly care. DOI: 10.1057/9781137031051.0006: Palgrave Macmillan. http://www.rgu.ac.uk/currentstudents/library/libraryhome/eresources/ebooks/ebooks-collections.

Igbinovia, J. 2013. Our elderly parents deserve quality care - Dr. Iyabode Cole -Vanguard News. Retrieved July 172014 from http://www.vanguard .com: http://www.vanguard .com/2013/01/our-elderly-parents-deserve-qualitycare-dr-iyabo-cole/.

Jiboye, A.D. 2001. Homelessness in Lagos Nigeria: Challenges to Sustainable Development. Journal of Sustainable Development. 13: 138-154.

National Affordable Housing Association. 2006. Sustainability; Policy Areas. Retrieved from: http://www.housingcorp.gov.uk, on 6th October, 2014.

National Bureau of Statistics. 2007. Annual Abstract of Statistics, Produced under the auspices of Federal Government Economics Reform and Government Economics Reform and Government Project (ERGP). National Bureau of Statistics (NBS): Abuja.

National Population Commission (NPC). 1998. 1991 Population Census of the Federal Republic of Nigeria: Analytical Report at the National Level. National Population Commission (NPC) Block 14, Lukulu Street, Abuja, Nigeria.

National Population Commission (NPC). 2002. Nigerian Population Census 1991 Analysis: National and State Population Projections. Abuja: National Population Commission. 
National Population Commission (NPC) [Nigeria] and ICF Macro. 2009. Nigeria Demographic and Health Survey 2008. Abuja: National Population Commission and ICF Macro.

National Population Commission. 2006. Population and Housing Census Of The Federal Republic of Nigeria: National and state Population Housing Priority Tables. National Population Commission: Abuja. Vol. I.

NEMA. 2008.Why Nigerians are Prone to Fire Disasters, Buildings Collapse. Sunday Vanguard. February 24th.

Novak, M. 2008. Issues in Aging. Boston: Pearson Education Inc.

Obasharo-John, O. 2011. Global Aging Issues: The Nigerian Situation. Journal of Aging in Emerging Economies. Via www.kent.edu/sociology/resources/jaee/upload/obashoro.pdf. Accessed 01/01/2014.

Oboh, N. 2011. Beggars Deported back to their States from Abuja. Via http://www.nairaland.com/704764/beggars_deported_back_states_abuja.

Okumagba, P.O. 2011. Family Support for the Elderly In Delta State of Nigeria. Via http://www.krepublishers.com/02-Journals/S-HCS/HCS-050-000-11-Web/HCS-05-1-000-11-Abst-PDF/HCS-05-1-021-11-146Okumagba-P-O/HCS-05-1-021-146-Okumagba-P-O-Tt.pdf.

Olalekan, T.M. and Ola, M.A. 2012. Socio-Demographic Correlates of Elderly Abuse in Ado-Ekiti, Nigeria. International Journal of Humanities and Social Sciences. Special issue. 3(2): 299-306.

Olatunji, O.E. 2012. The Political Economy of Pharmaceutical Healthcare in Third World Countries: A Case Study of Malaria in Sub-Saharan Africa. ProJournal of Humanities and Social Science (PHSS). 2(1): 23-45.

Older Homeless People. 2009. Via http://www.homeless.org.UK/olderhomeless.

Olori, T. 2006. Villagers Flee Landslides. New Nigerian. November 2, 2008. 38.

Olugbile, O.B.; Coker, A.O. and Zaccharia, M.P. 2014. A Study on Homeless People in Lagos State, South West, Nigeria. International Journal of Psychiatry. Retrieved on 10th July 2014 via http://manuscript.sciknow.org/uploads/ijp/pub/ijp_1386157651.pdf. 1(1): 1-4.

Onoyase, A. 2010. Effective Methods of Combating Street Begging in Nigeria as Perceived by Panhandlers. Journal of Study Home Community Science. 4(2): 109-114.

Ottong, J.G.; Bassey, A.O. and Bassey, A.E. 2012. Integrating Cultural Values in Designing Specialized Institutional Care for the Elderly in Nigeria. Journal of Social Science and Public Policy. 4: 60-68.

Regional Geriatric Program of Toronto. 2012. The Aging and Homelessness Project. Viahttp://rgp.toronto.on.ca/print/aging_and_homelessness_project.

The City Reporters. 2014, March 12. Boko Haram: 57,000 Nigerians Refugees, 500,000 Homeless-UN. Retrieved July 172014 from http://thecityreporters.com:http://thecityreporters.com/boko-haram-57000-nigeria-refugees5000 . 
The Health of the Homeless - Living in Public: Increased Health Problems, 2013. Via http://www.libraryindex.com/pages2318/health-homeless-livingin_public-increased_health_problems. Net Industries and its Licensors.

The Impact of homelessness Via http://www.focusireland.ie/files/docs /Impact081.pdf.

United Nations Centre for Human Settlements (UNCHS). 2000. Strategies to Combat Homelessness. UN: Nairobi. Retrieved July 3rd 2014, via https://habnet.unhabitat.org/files/1774_homeless.pdf.

Uzondu, J. 2010. Empowering Beggars. In Nigerian Newsworld Magazine, via http://www.nigeriannewsworld.com/content/empowering-beggars. 